Available online at GSC Online Press Directory

GSC Biological and Pharmaceutical Sciences

e-ISSN: 2581-3250, CODEN (USA): GBPSC2

Journal homepage: https://www.gsconlinepress.com/journals/gscbps

(RESEARCH ARTICLE)

\title{
Extracellular enzymes and ßeta-lactamase screening of bacterial isolates cultured from urine samples of immunocompromised women
}

\author{
Olagoke O. V ${ }^{1,2}{ }^{*}$, Alao B. I. ${ }^{2}$, Jimoh J. O. ${ }^{2}$ and Ladipo T. O. ${ }^{2}$ \\ ${ }^{1}$ Department of Microbiology, Obafemi Awolowo University, Ile-Ife, Osun State, Nigeria. \\ 2 Department of Agricultural Development Management, Agricultural and Rural Management Training Institute \\ (ARMTI), Ilorin, Nigeria.
}

Publication history: Received on 05 June 2018; revised on 13 August 2018; accepted on 20 August 2018

Article DOI: https://doi.org/10.30574/gscbps.2018.4.3.0043

\begin{abstract}
Enzymes intricate by organisms are used to inactivate and destroy antibiotics. This study determined some virulence factors elaborated by the bacterial isolates cultured from urine samples of HIV seropositive pregnant women that attended antenatal clinic of the Ondo State Specialist Hospital, Akure. Screening for extracellular enzymes and extended spectrum beta lactamase (ESBL) of the isolate was carried out using standard method and disk approximation method respectively. The extracellular enzymes such as lipase, protease and DNase were detected in the three bacterial genera used. ESBL was found in S. aureus and E. coli. The study concluded that most of the bacterial isolates cultured from urine samples of HIV seropositive pregnant women in the study area were found to have these virulence factors.
\end{abstract}

Keywords: Screening; Extracellular enzymes; Bacteria; HIV seropositive

\section{Introduction}

Enzymes intricate by organisms are used to inactivate and destroy antibiotics. Beta-lactamases are enzymes capable of hydrolyzing beta-lactam antimicrobials and at the same time inactivating them [1]. There are hundreds of different beta-lactamase enzymes which differ in terms of the specific beta-lactam antimicrobials they are able to inactivate [1]. Extended-spectrum beta-lactamases (ESBLs) are beta-lactamase enzymes capable of hydrolyzing extended-spectrum or third generation cephalosporins (e.g., ceftriaxone and/or ceftazidime) [2]. They do not hydrolyze carbapenems and they are susceptible, in turn, to inhibition by conventional beta-lactamase inhibitors (clavulanate) [3].

ESBL producing organisms remain an important cause of therapy failure with beta-lactam antibiotics and have a serious impact on infection control [4]. Therefore, the detection of ESBL producing organisms and the correct choice of antibiotics is important [5]. Large numbers of outbreaks due to ESBL producing organisms have been reported around the world and their prevalence is increasing [6]. The extended spectrum beta-lactamases (ESBLs) enable certain Gramnegative bacteria to inactivate cephalosporins as well as broad-spectrum penicillins and monobactams (aztreonam). ESBL production by Gram-negative organisms is an emergent, worldwide problem [7] and the presence of these enzymes has an impact on the efficacy of $\beta$-lactam therapy $[2,8]$. ESBLs can present variations in the in vitro pattern of resistance to $\beta$-lactam agents conferred to the samples that encode them [9].

Recovery of antibiotic-resistant, especially to $\beta$-lactams, strains of Enterobacter is reported to be on the increase [10], particularly during therapy with $\beta$-lactam agent [2]. The molecular basis for the resistance in these Enterobacter isolates is a mutation to an ampD gene that normally prevents high-level expression of the chromosoma $\beta$-lactamase encoded by an ampC gene [5]. Studies done by Olagoke et al. [11] stated that plasmid induces the production of extra-cellular

\footnotetext{
${ }^{*}$ Corresponding author

E-mail address: victorolagoke@yahoo.com
}

Copyright (C) 2018 Author(s) retain the copyright of this article. This article is published under the terms of the Creative Commons Attribution Liscense 4.0. 
enzymes called $\beta$-lactamases, and also encoded resistance genes which are often located within genetic elements. The aim of the study is to screen and determine some virulence factors elaborated by the bacterial isolates.

\section{Material and methods}

\subsection{Materials}

Bacterial isolates (Staphylococcus aureus, Escherichia coli and Pseudomonas spp) cultured from the urine samples of HIV seropositive pregnant women attending antennal clinic at the Ondo State Specialist Hospital, Akure, South western, Nigeria were used for the study. Each bacterial isolate was verified using cultural morphology, Gram's staining, selective media and differential media as well as biochemical tests.

\subsection{Determination of extracellular enzyme production `}

Determination of extracellular enzyme production of all bacterial isolates was carried out for their ability to produce protease, lipase and DNase using specific media (skimmed milk agar, tributyrin agar and DNase agar respectively).

\subsubsection{Screening for lipase production}

All the bacterial isolates were streaked on solid tributyrin agar medium [12] containing (g/L), peptone from meat 2.5; peptone from casein 2.5; yeast extract 3.0; agar-agar 15.0 and $10.0 \mathrm{ml}$ tributyrin (glycerol tributyrate), pH was adjusted to 7.5. The presence of clear zone around the colonies indicated lipase production. The diameter of clear zone was measured for each colony.

\subsubsection{Screening for protease production}

All the bacterial isolates were streaked on solid skimmed milk agar medium containing peptic digest of animal tissue 5.0, beef extract 1.5, yeast extract 1.5, sodium chloride 5.0, agar 15.0 and skimmed milk $10.0 \mathrm{in} \mathrm{g/l.}$

\subsubsection{Screening for DNase}

The 1 to 2 colonies of $24 \mathrm{~h}$ old culture of each bacterial isolate was inoculated on set DNase plates by streaking. The plates were incubated at $37^{\circ} \mathrm{C}$ for 24 hour. After $24 \mathrm{~h}$ after which it was flooded with $1 \mathrm{~N} \mathrm{HCl}$. A zone of inhibition indicates DNase activity.

\subsection{Screening for extended spectrum betalactamase}

Screening for extended spectrum betalactamase was done by using double disk approximation method [13]. Test strains were incubated in nutrient broth at $37^{\circ} \mathrm{C}$ to an optical density of $0.5 \mathrm{McF}$ arland turbidity standards. This suspension was inoculated onto a Mueller-Hinton Agar plate by swabbing with sterile cotton swabs. Two antimicrobial disks were placed $30 \mathrm{~mm}$ apart (Centre to Centre). One of the disks contained amoxicillin/clavulanic acid and the other contained an expanded-spectrum cephalosporin (ceftriaxone).

\section{Results}

\subsection{Determination of extra cellular enzymes production}

Determination of extra cellular enzymes production of bacterial isolates recovered from urine samples of HIV seropositive pregnant women were carried out for their ability to produce certain enzyme. Out of fifty bacterial isolates, fifteen of Staphylococcus aureus, one of Escherichia coli and five of Pseudomonas spp were positive for lipase. For protease screening, twelve of Staphylococcus aureus and five of Pseudomonas spp were positive. While twenty of Staphylococcus aureus, five of Pseudomonas spp and one of Escherichia coli were positive for DNase screening.

\subsection{Screening for extended spectrum beta lactamase (ESBL)}

This was done by using double disk approximation method [13]. Four out of ten Escherichia coli and two out of twenty Staphylococcus aureus were positive for ESBL. 


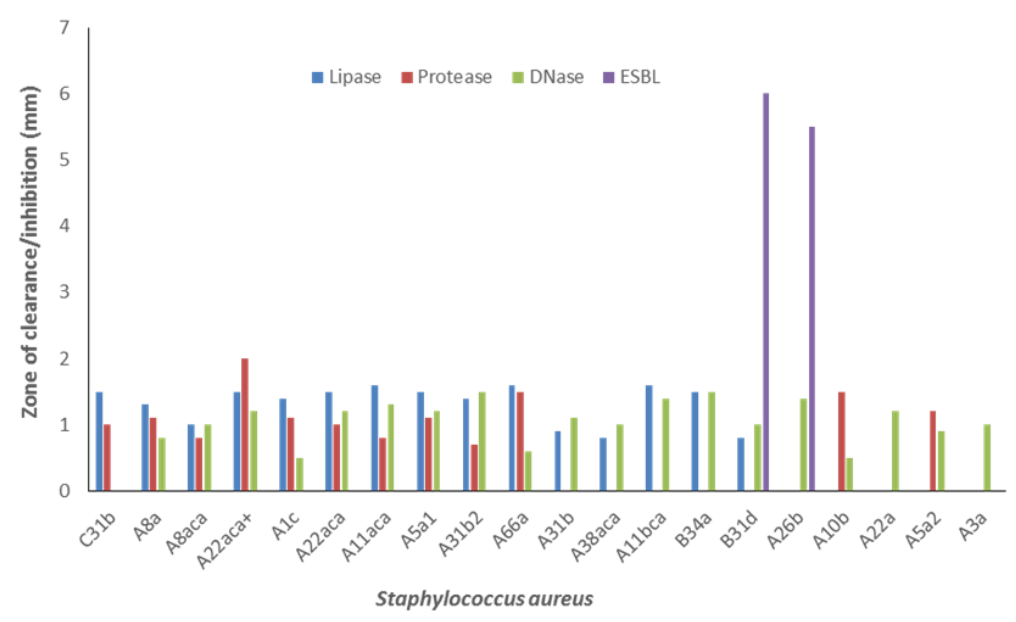

Figure 1 Extracellular enzymes produced by S. aureus isolates

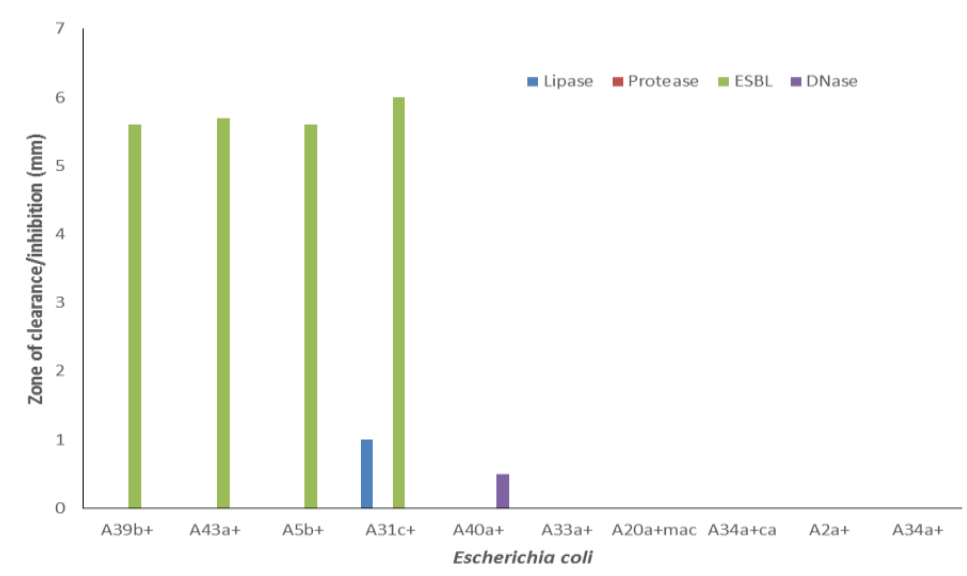

Figure 2 Extracellular enzymes produced by E. coli isolates

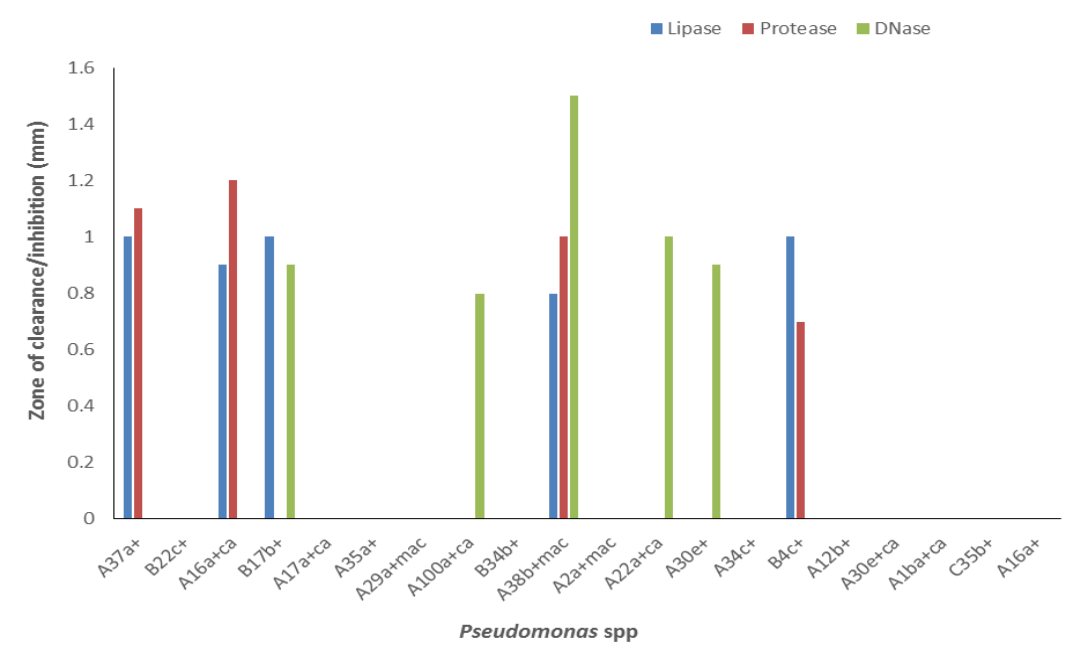

Figure 3 Extracellular enzymes produced by P. aeruginosa and P. fluorescens isolates

\section{Discussion}

Enzymes elaborate by organisms are used to inactivate and destroy antibiotics. The previous study revealed that the production of enzyme is both constitutive and inductive which suggests that the enzyme could be an intrinsic defense 
of the organisms against the effect of antibiotics used. The bacterial isolates were screened for the production of enzyme protease, lipase, and DNase. Of the $20 \mathrm{~S}$. aureus isolates tested, ten (10) isolates were found to produce three of these enzymes each (protease, lipase, and DNase), five bacterial isolates produced DNase and lipase enzymes, two bacterial isolates produced DNase and protease while the remaining three bacterial isolates produced DNase enzyme only. Ten E. coli isolates screened for enzyme production showed that one bacterial isolate produced DNase enzyme, another bacterial isolate produced lipase and another protease. Also, of the twenty Pseudomonas spp cultured, (13 Pseudomonas aeruginosa and 7 Pseudomonas fluorescens) 6(46.2\%) out of 13 P. aeruginosa isolates produced enzymes. Two of which produced lipase and protease each, one produced lipase and DNase while the remaining three produced DNase only. On the other hand, $2(28.6 \%)$ out of 7 P. fluorescens isolates recovered showed that one of the two P. fluorescens produced lipase and protease and the other one produced three enzymes, lipase, protease and DNase.

Production of extended spectrum beta lactamase (ESBL) was detected in this study. According to Tumane and Durgesh (2013), the ESBL producing bacterial causes various life threatening infections which could lead to sepsis related mortality [14]. Of the ten E. coli isolates screened for ESBL, four isolates produced ESBL, while Pseudomonas aeruginosa and Pseudomonas fluorescens isolates were found to be ESBL negative. Of the twenty $S$. aureus isolates screened for ESBL, two isolates were ESBL positive, this is rear information compared to previous researches done and it may be a new idea or innovation in research area. This study highlights the need to establish an antimicrobial resistance surveillance network for ESBL/extracellular producing bacterial isolates to monitor the trends and new types of resistance mechanisms in Nigeria.

\section{Conclusion}

The study concluded that most of the bacterial isolates cultured from urine samples of HIV seropositive pregnant women in the study area were found to have these virulence factors. Also, the enzyme screening revealed that most of the enzyme-producing bacteria produced more than one analyzed enzyme. Finally, the study recommend that the factors responsible for the selection and dissemination of ESBL-producing strains need to be identified, controlled and where possible, to prevent in order to avoid major outbreaks of such strains in the country.

\section{Compliance with ethical standards}

\section{Acknowledgments}

The authors would like to express their sincere thanks to all staffs of department of Microbiology, Obafemi Awolowo University Ile-Ife, Osun State. Nigeria for allowing this research work to be carried out successfully. Besides, the authors also express gratitude to Professor K.A. Ako-Nai for his excellent supervision during the period of laboratory work.

\section{Disclosure of conflict of interest}

None declared.

\section{References}

[1] Bush K and Jacoby GA. (2010). Updated functional classification of $\beta$-lactamases. Antimicrobial Agents Chemotherapy, 54, 969-76.

[2] Bradford PA. (2001). Extended-spectrum $\beta$-lactamases in the $21^{\text {st }}$ century: Characterization, epidemiology, and detection of this important resistance threat. Clinical Microbiology Reviews, 14, 933-51.

[3] Pfaller MA and Segreti J. (2006). Overview of the epidemiological profile and laboratory detection of extendedspectrum $\beta$-lactamases. Clinical Infectious Disease, 42(4), S153-63.

[4] Livermore DM. (2003). Bacterial resistance: origins, epidemiology, and impact. Clinical Infectious Disease, 36(1), S11-23.

[5] Lim YK, Lee MK and Kim TH. (2015). (2015). Management of extended-spectrum beta-lactamase-positive gramnegative bacterial urologic infections. Urogenital Tract Infection, 10(2), 84-91.

[6] Rupp ME and Fey PD. (2003). Extended spectrum beta-lactamase (ESBL)-producing Enterobacteriaceae: considerations for diagnosis, prevention and drug treatment. Drugs, 63, 353-65. 
[7] Bell JM, Turnidge JD and Gales AC. (2002). Prevalence of extended spectrum $\beta$-lactamase (ESBL) producing clinical isolates in the Asia-Pacific region and South Africa: regional results from SENTRY Antimicrobial Surveillance Program (1998-99). Diagn Microbiology Infectious Disease, 42, 193-8.

[8] Bush K. (2001). New $\beta$-lactamases in Gram-negative bacteria: Diversity and impact on the selection of antimicrobial therapy. Clinical Infectious Disease, 32, 1085-9.

[9] Livermore DM. (1995). $\beta$-lactamases in laboratory and clinical resistance. Clinical Microbiology Reviews, 8, 55784.

[10] Oplustil CP, Nunes R and, Mendes C. (2001). Multicenter evaluation of resistance patterns of Klebsiella pneumoniae, E. coli, Salmonella sp. and Shigella sp. isolated from clinical specimens in Brazil: Resisant Surveillance Program. Brazil Journal of Infectious Disease, 5, 8-12.

[11] Olagoke OV, Oyewale O0, Olufehinti MO and Adesina BS, (2018). Plasmid Profile of Bacteria. International Journal of Current Microbiology and Applied Science, 7(06), 2319-7706

[12] Smibert RM, and Krieg NR. (1981). General characterization. In Manual of Methods for General Bacteriology, Edited by P. Gerhardt and others. Washington, DC: American Society for Microbiology, 409-443.

[13] Thomson KS and Sanders CC. (1992). Detection of extended-spectrum beta-lactamases in members of the family Enterobacteriaceae: comparison of the double-disk and three-dimensional test. Antimicrobial Agents Chemotherapy, 36(11), 1877-1882.

[14] Tumane PM and Durgesh DW. (2013). Occurrence of extended spectrum beta-lactamase producing Enterobacteriaceae causing wound infections. Asian Journal of Biomedical and Pharmaceutical Sciences, 3(20), 55-58.

\section{How to cite this article}

Olagoke OV, Alao BI, Jimoh JO and Ladipo TO. (2018). Extracellular enzymes and ßeta-lactamase screening of bacterial isolates cultured from urine samples of immunocompromised women. GSC Biological and Pharmaceutical Sciences, $4(3), 37-41$. 